\title{
Collection and marketing of Bitter Cola (Garcinia kola) in Nkwerre Local Government area, Imo State, Nigeria
}

\author{
Unaeze HC ${ }^{1}$, Oladele $\mathrm{AT}^{2}$ \& $\mathrm{Agu} \mathrm{LO}^{1}$ \\ ${ }^{1}$ Department of Agricultural Economics and Extension, University of Port Harcourt, Port Harcourt, Nigeria \\ ${ }^{2}$ Department of Forestry and Wildlife Management, University of Port Harcourt, Port Harcourt, Nigeria
}

\begin{abstract}
The study was carried out to assess the collection and marketing of bitter cola in Nkwerre Local Government Area of Imo State Nigeria, with a general objective of determining the profitability and the constraints of bitter cola trade in the area. A total of one hundred and ten respondents were randomly selected from five rural communities. Data were collected using a well-structured questionnaire and personal interview. Most of the collectors were males. Net profit of $\$ 200,157.00 \mathrm{k}$ (about $930 \mathrm{~K}$ euros) was recorded from sales of bitter cola by the respondents. The amount of cola collected per year was positively related to marital status, age, distance and cost of bitter cola; age and labour costs were also significant predictors. Constraints encountered by collectors and marketers include rot and decay during storage (99\%), poor storage facilities (97\%), pest and diseases $(88.2 \%)$ and labour costs $(68.2 \%)$. Recommendations based on the findings include providing financial resources in form of loans, grants or incentives in order to boost bitter cola production, increase income and reduce poverty. Research in the area of domestication, plantation establishment, preservation and storage of the seeds need to be encouraged.
\end{abstract}

Keywords: Net profit, production constraints, household income

\section{Introduction}

Commonly known as 'bitter cola' for the bitter attributes of the seed, Garcinia kola (Guttiferae) is a non-timber forest product exclusively tropical in distribution. Locally, the seed is used medicinally to treat cough and hypertension (Adebisi, 2004), and hence G. kola is symbolic and valued culturally across southern Nigeria. It is a typical non-timber forest product that generates income for many people in rural and urban areas in developing countries including Nigeria (Andel, 2006). It is known as "male kola" or "Aku ilu"in Igbo land, "Orogbo" in Yoruba and "Namijiri - goro" among the Hausas.

The tree is commonly found in humid lowland forests of Nigeria, Cameroun, Ghana and the Benin Republic. Other species of Garcinia found in Nigeria include smeathmanii, ovalivolia, brevipedievata and manii, with different fruit colours, aromatic strength and sizes. G.kola is characterized by a slow rate of growth; difficulties are always encountered in attempting to raise its seedlings. The tree has a naturally long gestation period which can last up to 10 - 15 years before flowering and fruiting (Adebisi, 2004), but Marcots' farming method can lead to fruiting after only $4-5$ years.

Ofor et al. (2004) identified several ethno-botanical uses to which the local people of Imo State in south-eastern Nigeria put Garcinia seeds. These include as antidotes to snake bite, poison or overdose, and use as a snake repellent. Among the Nkwerre clan of Imo State, $G$. kola is a very important and well recognized plant used for centuries to treat chest cold in traditional medicine (Okojie et al. 2009). Ofusori et al. (2008) reported improved respiratory function after 28 days use of cola extract on rats, supporting the folklore use among the Nkwerre clan. Eye-drops containing $0.5 \%$ extract of $G$. kola seeds also reduces eye pressure (Adefule-Ositelu et al. 2008). The market price of this important forest product is escalating annually due to an inadequate supply as a result of relying heavily on natural sources, which are supplemented hardly at all by collections from a few stands in farms and home gardens. 
Ladipo (2003) noted that in Nigeria less than $10 \%$ of the total annual crop of the bitter cola fruit or the kernel is harvested from planted trees, while the rest are collected from wild sources. Fruits are processed by separating seeds from the pulp, air-drying them locally and preserving them for marketing locally. In most cases non-timber forest product marketing involves intermediaries or middlemen who traverse the interior rural areas looking for primary collectors from wild sources, and then ship the product to urban markets. Middlemen distribute to retailers who have direct contact with consumers in urban areas. Data on profits from non-timber forest product marketing and its contribution to rural and national economies have not been properly recorded in developing countries due to lack of or scanty documentation (Sunderland, 2001). Many households make and sustain their livelihoods from the collection and marketing of various non-timber forest products in sub-Saharan Africa (Ogunwusi, 2012).

Over the last decades, observations as well as studies have shown that bitter cola collection from natural sources has declined significantly due to lack of improved planting materials and inadequate market outlay which has negatively affected farmers in terms of marketing of their produce (Adebisi 2004). Seasonal fluctuations in production, deforestation, pests and diseases, lack of adequate resource inputs, inadequate information, and the absence of good roads and modern techniques have reduced the motivation of collectors to source bitter cola from the forests. Presently there are few or no statistics on the economics within which bitter cola collectors operate to guide realistic policy and programme formulation to achieve profitability in the enterprise.

Thus we undertook an economic analysis of bitter cola collection and marketing. The specific objectives of this work were to evaluate the socio-economic characteristics of bitter cola farmers and collectors in the study area, determine how socio-economic factors affect bitter cola collection and marketing, assess the profitability of the bitter cola enterprise and identify any constraints.

\section{Materials \& Methods}

The study was carried out in Nkwerre Local Government Area of Imo State, Nigeria (located between latitudes $4^{\circ} 45 \mathrm{~N}$ and $7^{\circ} 15 \mathrm{~N}$, and longitudes $6^{\circ} 50 \mathrm{E}$ and $7^{\circ} 25 \mathrm{E}$ ). Imo state has an estimated population of almost two-and-a-half million people at the 2006 census (NBS, 2006). The climate is characterized by a uniformly high temperature which fluctuates between 23 and $30{ }^{\circ} \mathrm{C}$. The major tree crops grown include Cashew (Anarcadium occidentale), Avocado pear (Persia americana), African star apple (Chrysophyllum albidum) and Bitter cola (Garcinia kola). The local people are mainly involved in arable agriculture of cassava, cocoyam and maize. Bitter cola is not usually grown in large quantity; however, it is preserved on farms and occasionally planted on compound farms. The Local Government Area is comprised of twenty communities, out of which five are the main bitter cola collectors: these five were selected for the study: Amaokpara, Abo, Ama ike, Ama uju, Umuegbe (Imo State Government, 2013).

A well-structured and pre-tested questionnaire was then administered among 110 randomly selected bitter cola collectors and marketeers in the selected communities. Questionnaires were interpreted in the local language (Igbo) for proper understanding and responses carefully documented by the researchers. The data obtained from the questionnaire were analyzed using regression, and net profit calculated from the following:

Profit margin $=$ revenue - costs

Revenue $=$ price per $\mathrm{kg}$ x quantity

Costs $=$ variable costs + fixed costs

Gross margin $=$ revenue - variable costs

Net farm profit $=$ gross margin - fixed costs 
All values are in the local currency $(\mathrm{N})$. Variable costs include items such as the cost of labour. Fixed costs are derived through depreciation of the costs of fixed inputs, such as head pans, machetes, etc. The costs of collection and revenue consist of the sum for all the bitter cola collectors interviewed.

Linear multiple regression explored relationships between the response (dependent) variable of the total amount of bitter cola collected per year and a set of predictors (sex, age of farmer in years, marital status, level of education in years, farming experience in years, number of people in household, distance, cost of cola and labour costs). Both predictor and response variables were used in all combinations of untransformed and log-transformed format.

\section{Results}

Most of the bitter cola collectors were men, advanced in age (50-60) and very experienced in the trade (Table 1). Most of the respondents had only primary education, with only about a fifth with secondary education; a few had tertiary education and non- formal education. The majority were married, with a mean household size of 11 .

\begin{tabular}{lrcr}
\hline Characteristics & Frequency & Characteristics & Frequency \\
\hline Age (yrs) & & Marital status & \\
$20-29$ & 6 & Single & 9 \\
$30-39$ & 21 & Married & 72 \\
$40-49$ & 18 & Widow(er) & 21 \\
$50-59$ & 32 & Separated & 8 \\
60 and above & 33 & Household size & \\
Sex & & $1-5$ & 23 \\
Male & 69 & $6-10$ & 50 \\
Female & 41 & $11-15$ & 35 \\
Educational level & & Above 15 & 2 \\
Nil & 41 & Farming experience & \\
Primary & 43 & $1-10$ & 14 \\
Secondary & 12 & $11-20$ & 50 \\
Tertiary & 14 & $21-30$ & 35 \\
& & Above 30 & 11 \\
\hline
\end{tabular}

Table 1: Socio-economic characteristics of Bitter cola collectors and marketeers from field surveys in 2012.

The double-log model was the best fit in the regression analysis of the socio-economic characteristics that affect Bitter cola harvesting and marketing in the study area (Table 2). The significant coefficients for age, marital status, and the costs of Bitter cola and labour all showed positive relationships, indicating a direct effect on output. The coefficients for household size and length of experience were negative, indicating that older collectors and larger households collected less cola.

The net farm profit analysis determines the total income from bitter cola enterprise in the study area; the model used variable cost and fixed cost in calculating the net farm profit for the enterprise (Table 3). Net farm profit represents the respondents' average net farm profit. 


\begin{tabular}{ccccr}
\hline Variables & \multicolumn{3}{c}{ Double log model } \\
& Coefficient & t-stat & p-value \\
\hline Constant & 0.676 & 0.876 & 0.404 \\
Sex & -.104 & -.685 & .510 \\
Age & .484 & 1.759 & $* *$ & .010 \\
Marital status & .461 & 1.282 & $*$ & .023 \\
Education & .211 & 1.567 & .152 \\
Experience & -.039 & $-.136 \quad * *$ & .010 \\
Household & -.676 & -.599 & $*$ & .050 \\
Distance & 0.069 & 0.293 & .776 \\
Cost & .252 & $3.026 \quad *$ & .014 \\
Labour & .129 & -.986 & $*$ & 0.03 \\
& \multicolumn{5}{c}{ R square } & $\mathbf{0 . 8 0 4}$ \\
& \multicolumn{5}{c}{ F ratio } & $\mathbf{4 . 1 1 3}$ \\
& Sig & $\mathbf{0 . 0 2 3}$ \\
\hline
\end{tabular}

Table 2: Effects of socio-economic characteristics on Bitter cola collection and marketing, as assessed by multiple regression

\begin{tabular}{lrr}
\hline Items & Amount $(\mathbf{k ~ N})$ & $\mathbf{k} \boldsymbol{\epsilon}$ \\
Total Revenue & $\mathbf{2 3 6 , 0 9 0 . 0 9}$ & 1088 \\
Variable costs & & \\
$\quad$ Organic fertilizer & 1050.00 & 5 \\
$\quad$ Tools (baskets) & 1800.00 & 8 \\
$\quad$ Labour inputs/manday (land preparation) & 6800.00 & 31 \\
$\quad$ Weeding & 16800.00 & 77 \\
$\quad$ Other expenses & 1378.08 & 6 \\
Total variable costs & $\mathbf{2 7 8 2 8 . 0 8}$ & 128 \\
$\quad$ Gross margin & 208262.01 & 960 \\
$\quad$ Total fixed cost & 8105.01 & 37 \\
$\quad$ Total cost & 35933.09 & 166 \\
Net returns & $\mathbf{2 0 0 1 5 7 . 0 0}$ & 923 \\
\hline
\end{tabular}

Table 3: Average annual net return of Bitter cola in Nkwerre Local Government Area

\begin{tabular}{lccc}
\hline Constraints & Frequency & Percentage & Ranking \\
\hline Rot and decay during storage & 57 & 10.55 & $1^{\text {st }}$ \\
Poor storage facilities & 57 & 9.81 & $2^{\text {nd }}$ \\
Pest and diseases & 52 & 9.76 & $3^{\text {rd }}$ \\
High cost of labour & 51 & 9.41 & $4^{\text {th }}$ \\
Lack of credit facilities & 50 & 9.17 & $5^{\text {th }}$ \\
Lack of market information & 49 & 9.07 & $6^{\text {th }}$ \\
Low price of product & 46 & 8.51 & $7^{\text {th }}$ \\
Distance from farm to market & 42 & 7.77 & $8^{\text {th }}$ \\
Land scarcity and tenure & 37 & 6.85 & $9^{\text {th }}$ \\
Poor infrastructure facilities & 31 & 5.74 & $10^{\text {th }}$ \\
Low soil fertility & 26 & 4.81 & $11^{\text {th }}$ \\
Poor knowledge of technology of bitter cola propagation & 21 & 3.88 & $12^{\text {th }}$ \\
Lack of extension contact & 13 & 2.40 & $13^{\text {th }}$ \\
High cost of planting materials & 11 & 2.03 & $14^{\text {th }}$ \\
\hline
\end{tabular}

Table 4: Constraints on Bitter cola production in Nkwerre Local Government Area 
Factors limiting bitter cola production (Table 4) were ranked based on the major constraints affecting the study area. Seed rot and decay during storage $(10.55 \%)$ were noted as a major constraint affecting the producers. Deterioration and poor quality result in low market price of bitter cola seeds. Other constraints listed by the collectors and marketers include poor storage facilities, pest and diseases and low soil fertility.

\section{Discussion}

Men dominated the collection of bitter cola in the study area because of the drudgery of Bitter cola sourcing. Thus, women engaged mostly in marketing the seeds, while men did most of the harvesting and processing (Aiyeloja et al., 2012). In terms of educational status, many of the farmers had the ability and capacity to adopt new technologies and relevant information that would improve their collection and processing techniques. Similar observations were noted while assessing socio-economic characteristics affecting farmers elsewhere (Adebayo \& Adeola, 2005). The Bitter cola collectors had expanded households providing cheap labour during harvesting and processing (Awotide et al., 2011). The harvesting and marketing of nontimber forest products have been noted to support large households in rural areas during scarcity (Schreckenberg et al., 2006). The collectors were highly experienced in the collection, processing and marketing of bitter cola in order to sustain household needs.

Picking ripe Bitter cola fruits from the forest floor is not a strenuous activity, and hence there was no effect of gender on collection (Neumann \& Hirsch, 2000; Elia \& Carney, 2007). However, harvesting of some other non-timber forest products such as rattan, chewing stick (Massularia acuminata) and wine tapping from Raphia hookeri require physical strength and are usually carried out by men (Kalu \& Rachael, 2006). The effect of educational level of respondents was positive but not significant; this contrasts with the findings of Pannin \& Brummer (2000), who reported significance effects of educational level on farmer's socioeconomic characteristics. Marital status and labour costs had significant effects on profits from Bitter cola marketing. Married people with expanded households collect higher quantities of bitter cola from the wild than unmarried individuals in order to meet the needs of their family.

The net farm profit analysis is similar to other reports (Ofor et al., 2004; Babalola \& Agbeja, 2010) of appreciably high profit margins in the sales of Bitter cola by producers and intermediaries both in south-west and south-east Nigeria. Factors limiting Bitter cola production are similar to those identified by Nwauzor (2001), especially rot as one of the main problems militating against maximum fruit production. The same constraints were reported by Mbanaso et al. (2008) among Bitter cola producers in Cameroon. Most farmers use organic fertilizer to improve the soil and increase the yield of Bitter cola fruits.

Based on our findings, Bitter cola collection and marketing generates a good income for stakeholders despite factors militating against its production. Bitter cola sourcing in the study area is an enterprise that engages people of different productive ages. It is not genderspecific even though its sourcing is male-dominated. The enterprise provides important support for families, and constitutes a full-time occupation for more than half of the producers.

The government and poverty alleviation agencies need to provide credit facilities for farmers to enable them to acquire inputs and processing equipment. The government needs to encourage research in the area of preservation and storage of the seeds to ensure off-season availability. Improvements in marketing efficiency for increased profit also needs to be addressed. There is an urgent need for youth empowerment programmes since most of the respondents were within their productive ages. The collectors should be encouraged to form co-operative societies that can facilitate the credit facilities required for the propagation and establishment of plantations that will secure sustainable supplies. 


\section{References}

Adebayo OO \& Adeola RG (2005) Socio - economic factors affecting poultry farmers in Ejigbo Local Govt. Area of Osun State. Human Ecology 15(1): 39 - 41

Adebisi AA (2004) A case study of Garcinia kola nut production-to-consumption system in J4 area of Omo forest reserve, south-west Nigeria. pp 115-132 in Sunderland T \& Ndoye O (eds) Forest products, livelihoods and conservation: case studies of non-timber forest product systems. Vol. 2 Africa. CIFOR.

Adefule-Ositelu AO, Adegbehingbe BO, Adefule AK, Adegbehingbe OO, Samaila E \& Oladigbolu K (2010) Efficacy of Garcinia kola $0.5 \%$ aqueous eye drops in patients with primary open-angle glaucoma or ocular hypertension. Middle East African Journal of Ophthalmology 17(1): 88-93

Aiyeloja AA, Oladele AT \& Ezeugo OE (2012) Evaluation of non-timber forest products trade in Ihiala Local Govt. Area, Anambra State, Nigeria. International Journal of Science \& Nature 3(2):

Andel TV (2006) Non-timber forest products: the value of wild plants. Agromisa Publications \& CTA, The Netherlands.

Awotide BA, Diagne A, Awoyemi TT \& Ojehomon VET (2011) Household endowment and poverty reduction in rural Nigeria: evidence from rice farming households. Agricultural Journal 6(5): 274-284

Babalola FD \& Agbeja BO (2010) Marketing and distribution of Garcinia kola (Bitter kola) in southwest Nigeria: opportunity for development of a biological product. Egyptian Journal of Biology 12: 12-17

Elias M \& Carney J (2007) African Shea butter: a feminised subsidy from nature. Africa 77(1): 37-62

Imo State Government (2013) Nkwerre Local Government Council. www.imostate.gov.ng (Jan. 2013)

Kalu C \& Rachael E (2006) Women in processing and marketing of non-timber forest products: case study of Benin City, Nigeria. Journal of Agronomy 5(2): 326-331

Ladipo DO (1995) Physiological/morphological growth rate and fruit/nut yields in Garcinia kola trees on acid soils of Onne, Port-Harcourt. ICRAF In-House Report.

Mbanoso M (2008) Research finding for development policy makers and practitioners. Idzi, Sussex.

NBS (2006) National Bureau of Statistics: population census, Nigeria. www.nigerianstat.gov.ng (Feb. 2013)

Neumann RP \& Hirsch E (2000) Commercialisation of non-timber forest products: review and analysis of research. Center for International Forestry \& Research, Bogor, Indonesia.

Nwauzor EC (2001) Nematode problems and solutions of root and tubercrops in Nigeria. In : Akoroda MO \& Ngeve JM (eds). Proceedings of the 7th Triennial Symposium of the International Society for Tropical Root Crops (ISTRC). Cotonou, Oct.11-17, 1998: 545-552

Ofor MO, Ngobili CA \& Nwufor MI (2004) Ethno-botanical uses and trade characteristics of Garcinia kola in Imo State, Nigeria. International Journal of Agricultural Rural Development 5:140-144

Ofusori DA, Ayoka AO, Adelakun AE, Falana BA, Adeeyo OA, Ajeigbe KO \& Yusuf UA (2008) Microanatomical effects of ethanolic extract of Garcinia kola on the lung of Swiss albino mice. The Internet Journal of Pulmonary Medicine 10(1)

Ogunwusi AA (2012) Challenge of industrial production and processing of Rattans in Nigeria. Journal of Research in National Development 10(2): 50-59

Okojie A, Ebomoyi M, Ekhator C, Emeri C, Okosun J, Onyesu G, Uhuonrenren O \& Atima J (2009) Review of physiological mechanisms underlying the use of Garcinia kola in the treatment of asthma. The Internet Journal of Pulmonary Medicine. 11(1)

Panin A \& Brummer B (2000) Gender differentials in resource ownership and crop productivity of smallholder farmers in Africa: a case study. Quarterly Journal of International Agriculture 39(1): 93-107

Schreckenberg K, Marshall E \& Willem te Velde D (2006) NTFP commercialization and the rural poor: more than a safety net? In: Marshall E, Schreckenberg K \& Newton AC (eds). Commercialization of non-timber forest products: factors influencing success, lessons learned from Mexico and Bolivia, and policy implications for decision-makers. UNEP World Conservation Monitoring Centre, Cambridge, UK. 71-76

Sunderland TCH (2001) Cross-river state community forest project: non-timber forest products advisor. Department for International Development, ERM Reference 6133, London. 


$$
\begin{aligned}
& \text { الملخص العربي } \\
& \text { جمع وتسويق الكو لا المرة (Garcinia kola) فى منطقة نكيررى المحلية ـ ولاية إمو - نيجيريا } \\
& \text { إينايزى هـ. س1 - أو لاديلى أ. ت.2 - أجو ل. و.1. }
\end{aligned}
$$

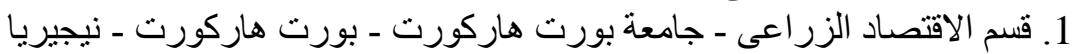

$$
\begin{aligned}
& \text { 2. قسم الغابات و إدارة الحياة البرية ـ جامعة بورت بورت هاركورت بورت ـ نيجيريا }
\end{aligned}
$$

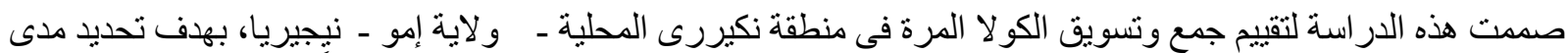

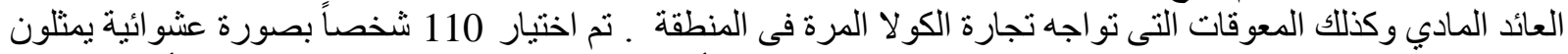

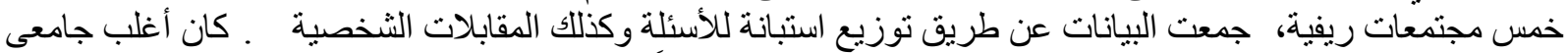

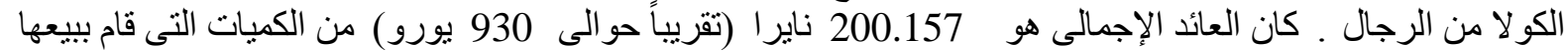

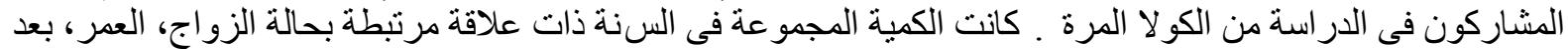

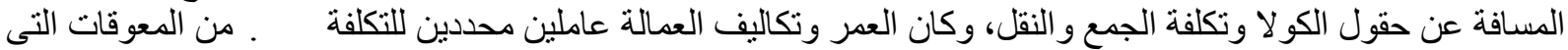

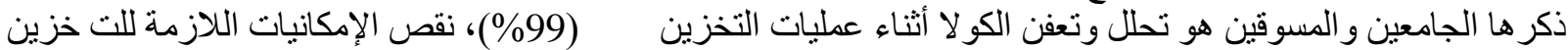

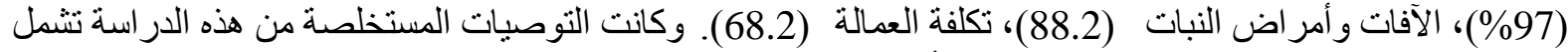

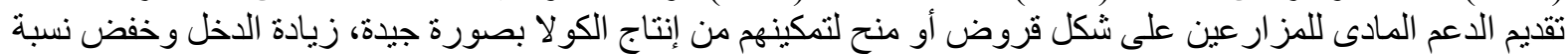

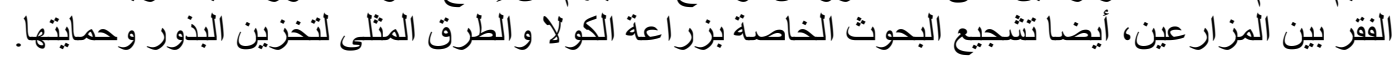

